\title{
The use of intraoperative epiaortic ultrasonography in monitoring patients over 75 years old treated with aortic valve replacement
}

\author{
Tomasz Niklewski ${ }^{1}$, Michał Zembala ${ }^{1}$, Dariusz Puszczewicz ${ }^{1}$, Paweł Nadziakiewicz², Wojciech Karolak ${ }^{1}$, \\ Marian Zembala ${ }^{1}$
}

\author{
${ }^{1}$ Department of Cardiac, Vascular and Endovascular Surgery and Transplantology, SMDZ in Zabrze, Medical University of Silesia \\ in Katowice, Silesian Center for Heart Diseases, Zabrze, Poland \\ 2Department of Cardiac Anesthesiology and Intensive Care, SMDZ in Zabrze, Medical University of Silesia in Katowice, \\ Silesian Center for Heart Diseases, Zabrze, Poland
}

Kardiochirurgia i Torakochirurgia Polska 2017; 14 (1): 10-15

\begin{abstract}
Introduction: Epiaortic ultrasound scanning (EAS) extended the use of ultrasound to the intraoperative diagnosis of aortic pathology. Surgical palpation of the ascending aorta underestimates the presence and severity of atherosclerotic plaques. Epiaortic ultrasound scanning has been used as an adjunct to transesophageal echocardiography (TEE) or as a primary direct diagnostic tool for imaging the ascending aorta as well as the aortic arch, which gained prominence as part of a multipronged intraoperative strategy to reduce atherosclerotic emboli.

Aim: To compare the epiaortic examination with transthoracic and transesophageal echo (transthoracic echocardiography (TTE) and TEE), X-ray, surgical intraoperative palpation, and postoperative neurological status.
\end{abstract}

Material and methods: The analyzed group consisted of $35 \mathrm{pa}-$ tients (mean age: 81.3 years) treated with aortic valve replacement (AVR), either alone (60\%) or combined with coronary artery bypass grafting (CABG; $22.8 \%$ ) or aortic aneurysm replacement (11.42\%). In 2 patients, only CABG was performed because intraoperatively reevaluated strategy. Thierteen patients have got a history of diabetes, 10 chronic renal failure and 3 of cerebral stroke.

Results: In more than $80 \%$ of patients, positive EAS results had an influence on the choice of aortic clamping site and in 50\% of patients on the site of cannulation. Female sex, peripheral vascular disease, history of previous stroke, and calcifications in the ascending aorta in TTE have significant predictive value for recognizing atherosclerotic changes in EAS and the risk of postoperative neurological complications in octogenarians treated with AVR.

Conclusions: Epiaortic ultrasound scanning imaging is superior to TTE and manual palpation in the detection and localization of ascending atherosclerosis. This technique should be

\section{Streszczenie}

Wstęp: Epikardialna ultrasonografia (EAS) została wprowadzona do praktyki klinicznej jako technika uzupełniająca ocenę nieinwazyjną podczas zabiegów chirurgicznych u starszych chorych z nasiloną miażdżycą. Obrazuje ona z powierzchni aorty zmiany miażdżycowe $\mathrm{w}$ konkretnym, podejrzanym palpacyjnie miejscu, a także pozwala kardiochirurgowi na wybór optymalnego miejsca zamknięcia aorty lub nawet zmianę strategii zabiegu chirurgicznego.

Cel: Analiza porównawcza badania nasierdziowego aorty wstępującej z obrazami echokardiograficznego badania przezklatkowego i przezprzełykowego (TTE i TEE), z badaniem radiologicznym, a u części chorych z badaniem tomografii komputerowej oraz oceną śródoperacyjną i pozabiegowym badaniem neurologicznym.

Materiał i metody: W badaniu wzięło udział 35 chorych w wieku średnio 81,3 roku, w tym 17 kobiet. U 21 (60\%) przeprowadzono zabieg chirurgicznej wymiany zastawki aortalnej (AVR), u 8 (22,85\%) wymiany zastawki wraz z pomostowaniem aortalno-wieńcowym (CABG), u 4 (11,42\%) wymiany aorty wstępującej (AAA), a u 2 chorych (5,71\%) jedynie zabieg pomostowania bez AVR. Spośród badanych 13 osób chorowało na cukrzycę, u 10 rozpoznano przewlekłą niewydolność nerek, natomiast 3 miało w wywiadzie przebyty udar mózgu.

Wyniki: U ponad 80\% chorych dodatni wynik badania EAS miał wpływ na wybór miejsca założenia klemu aortalnego, a u 50\% chorych - kaniulacji aorty. Płeć żeńska, zmiany miażdżycowe w naczyniach szyjnych, przebyty udar mózgu oraz zwapnienia w zakresie aorty wstępującej uwidocznione w przedoperacyjnym TTE okazały się parametrami, które rozpoznane jednocześnie $w$ istotny sposób są związane $z$ dodatnim wynikiem badania EAS.

Wnioski: Epikardialna ultrasonografia wraz z badaniem TTE i oceną palpacyjną aorty stanowi niezwykle przydatną techni- 
introduced as a standard perioperative examination in older patients at risk of neurological complications.

Key words: epiaortic ultrasonography, episcan, aortic valve, aorta.

\section{Introduction}

According to data from the Euro Heart Survey, the average age of patients undergoing cardiac surgery procedures rises continuously with the aging of the population. Some patients are not referred for these procedures due to numerous health burdens, while others have been offered hope in the form of minimally invasive treatment, such as off-pump coronary artery bypass (OPCAB), transcatheter aortic valve implantation (TAVI), minimally invasive mitral valve repair, and procedures using so-called mini-thoracotomy. Unfortunately, only the OPCAB and TAVI procedures are not associated with the use of extracorporeal circulation, which requires aortic clamping. The aortas of most elderly individuals, especially those above 75 years of age, are much less suitable for clamping than those of younger patients. Moreover, the number of vessel wall calcifications diagnosed in such patients is significantly higher. Apart from injuring the aortic wall, clamping the aorta with a metal clamp at the location of any wall calcification may also cause fragments of the calcified tissue to detach, leading to perioperative ischemic stroke [1]. Most patients undergoing cardiac surgery procedures involving the valves are monitored with intraoperative transesophageal echocardiography (TEE); unfortunately, this examination is insufficient for differentiating changes within the aortic wall, especially at the location where the clamp is applied, which is not covered by TEE imaging. Preoperative coronary angiography or routine chest $\mathrm{X}$-ray examinations are rarely able to visualize calcifications, and only if the lesions are large. Only the relatively expensive method of computed tomography is capable of visualizing the distribution of lesions within the aortic wall before surgery [2, 3].

Epiaortic scanning (EAS) was introduced into clinical practice in the early 1970s; initially, the method was used to monitor aortic valve function in patients undergoing cardiac surgery procedures. The role of this technique diminished after the introduction of TEE. Notwithstanding, EAS is still used to supplement noninvasive evaluation during surgical procedures; it can be used to present the image of atherosclerotic changes directly from the surface of the aorta, visualizing locations suspected after palpation that are usually inaccessible to TEE imaging, such as the distal segment of the ascending aorta or the aortic arch (Fig. 1). The high resolution of epicardial echocardiographic examinations using a transducer applied directly to the aorta after the patient's chest is opened enables detailed visualization of the aortic wall and its individual layers; in particular, the method can show the distribution of calcified atherosclerotic lesions in the ascending aorta and the aortic arch that sometimes cannot be detected by palpation. This enables the cardiac surgeon to select the optimal, safe location of closing the aorta or even change the operative strategy $[4,5]$. kę obrazową u starszych chorych z ryzykiem wystąpienia powikłań neurologicznych poddawanych zabiegom AVR.

Słowa kluczowe: epikardialna ultrasonografia nasierdziowa, zastawka aortalna, aorta.

\section{Aim}

The aim of this clinical study, conducted at the Department of Cardiac Surgery of the Silesian Center for Heart Diseases in Zabrze, was to compare epicardial examinations of the ascending aorta with transthoracic and transesophageal echocardiography (TTE and TEE), X-ray evaluation, computed tomography, intraoperative morphological evaluation, and detailed postoperative neurological assessment. The obtained results will enable the identification of patients who are at the highest risk of central nervous system (CNS) ischemia and the establishment of a perioperative management strategy.

\section{Material and methods}

The study encompassed 35 patients older than 75 years of age (average: 81.3 years) undergoing surgical aortic valve replacement (AVR) as an isolated procedure $(n=21,60 \%$ of patients) or valve replacement combined with coronary artery bypass grafting (CABG; $n=8,22.85 \%$ ) or with replacement of the ascending aorta due to an aneurysm (AAA; $n=4,11.42 \%)$; it also included 2 cases (5.71\%) in which the procedure type was changed to $C A B G$ or OPCAB alone (without AVR) due to the severity of atherosclerotic lesions in the ascending aorta.

Because of the costs associated with tomographic examination, the oldest patients (about 80 years old) were selected for the analysis. The study group included 17 women and 18 men (48.5\% vs. $51.5 \%$ ).

Thirteen patients had type II diabetes, 10 were diagnosed with chronic kidney disease, and 2 had previously suffered from a stroke (Tab. I).

All patients underwent routine $\mathrm{X}$-ray examination and TTE. The oldest patients with the highest perioperative risk, who were initially considered as potential candidates for transcatheter treatment (TAVI), underwent preoperative

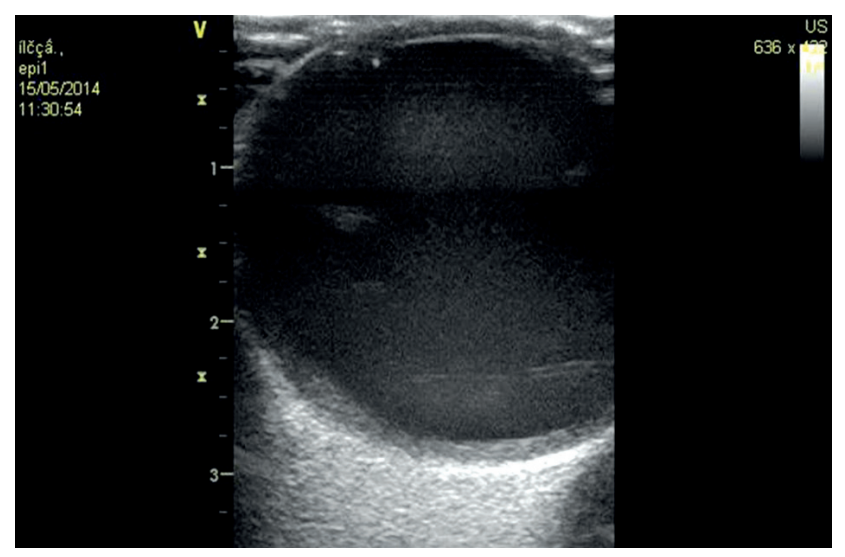

Fig. 1. Epiaortic scan (EAS): segment of the ascending aorta 
Tab. I. Medical history and physical examination parameters

\begin{tabular}{lcc} 
Clinical parameter & N & $\%$ \\
\hline Type 2 diabetes & 13 & 37.1 \\
\hline EF $<50 \%$ & 12 & 34.28 \\
\hline Renal failure & 10 & 28.57 \\
\hline Previous stroke & 2 & 5.71 \\
\hline COPD & 8 & 22.85 \\
\hline
\end{tabular}

$\mathrm{EF}$ - ejection fraction, COPD - chronic obstructive pulmonary disease.

computed tomography (CT) of the ascending aorta with a SIEMENS device. The diagnostics also included evaluation of flow in the carotid arteries and (in some cases) peripheral vessels.

Intraoperative TEE was conducted with a state-of-theart Phillips iE33 4D apparatus and supplemented with evaluation using an epicardial transducer (VIVID S6 manufactured by GE) (Fig. 2).

All EAS examinations were performed in the operating room using a linear transducer (i 12L RS, manufactured by $\mathrm{GE})$ with operating frequencies ranging from 5 to $13 \mathrm{MHz}$; the transducer is intended for aortic and vascular examinations and Doppler flow assessment (shallow tissue depth) and is compatible with the Vivid S6 device, with particular focus on morphology, measurements of the diameter and wall thickness of the ascending aorta, and localization of calcifications.

The transducer was placed in a sterile foil sleeve with a small amount of sterile ultrasound gel at the end.

The extent of changes in each of the 6 segments of the ascending aorta was evaluated using both CT and EAS. The results were entered into a table depending on the extent of calcification defined as the percentage of the circumference of each aortic segment occupied by organic changes, with particular focus on hard, calcified plaques (Figs. 3, 4).

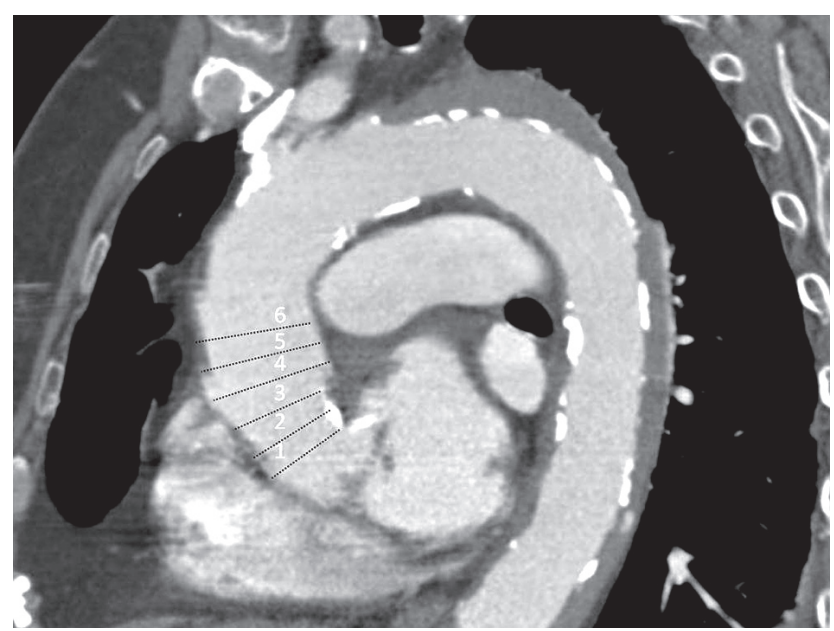

Fig. 3. Computed tomography (CT) examination, left lateral projection: the 6 segments of the ascending aorta evaluated in the patient in whom preoperative CT was performed are marked

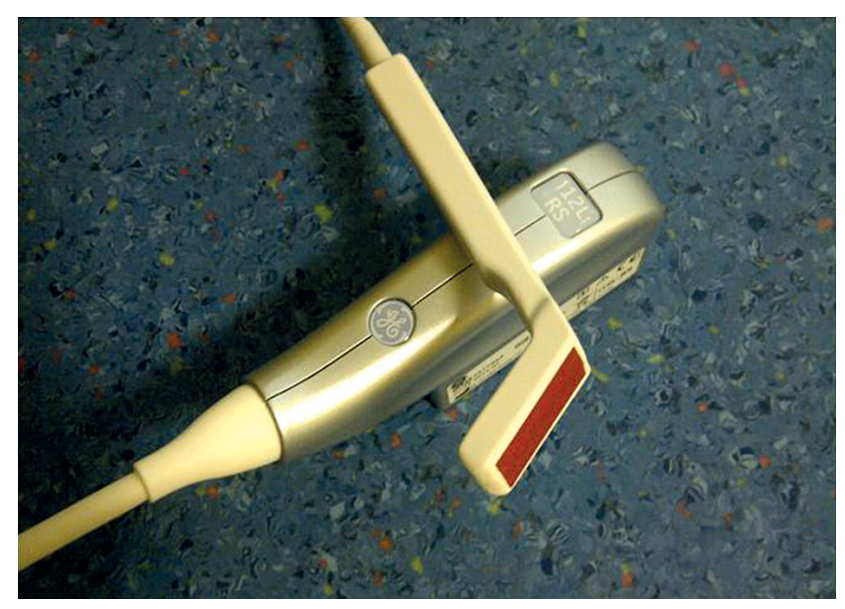

Fig. 2. Linear transducer (General Electric) adapted to the Vivid S6 device to perform ultrasonographic evaluation of the aorta and peripheral vessels

\section{Statistical analysis}

Statistical analysis was conducted with Statistica software, using Student's $t$-test to compare 2 independent groups; values of $p<0.05$ were considered statistically significant.

\section{Results}

The obtained results are presented in tables below. Clinical and statistical analysis was performed to compare patients diagnosed with atherosclerotic changes in the ascending aorta with patients in whom no such changes were revealed by epicardial examinations. Ultrasonography demonstrated the presence of atherosclerotic changes in the carotid arteries and the aorta in 23 (65.7\%) patients, while in $20(57.1 \%)$ patients the lesions were located in peripheral vessels (Tab. II).

None of the patients required the abandonment of the planned surgical procedure. However, the results of the EAS examination forced the surgeon to change the site where

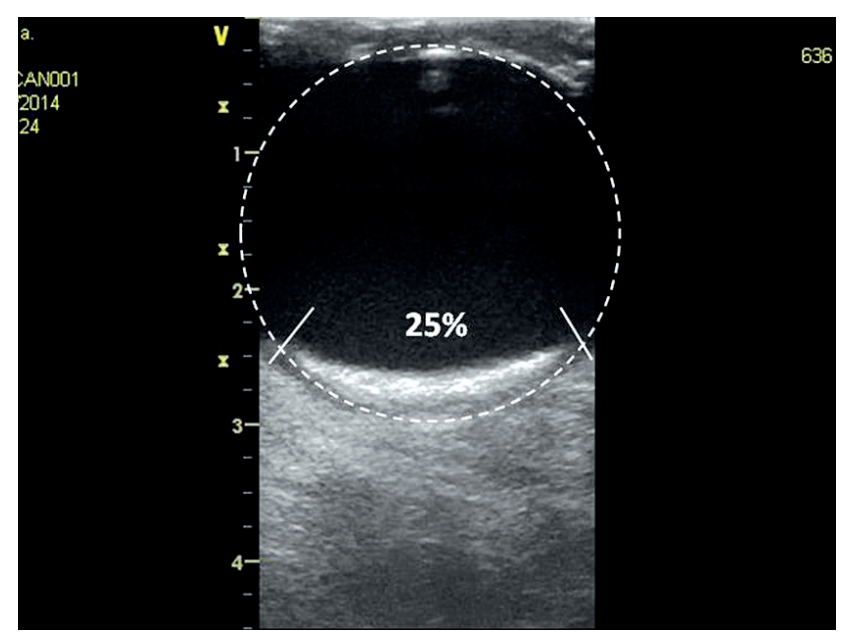

Fig. 4. Epiaortic scan image with the percentage of the vessel's diameter affected by the calcified wall lesion (corresponds to segment 1 of the computed tomography examination above) 
the ascending aorta was clamped and cannulated in 18 $(60 \%)$ cases (Tab. III).

\section{Neurological complications}

During the procedure, the patients were under continuous monitoring of cerebral perfusion; postoperatively, they underwent detailed analysis of cognitive parameters with an appropriate test for psychological evaluation and received neurological consultation.

With regard to neurological complications, the analysis encompassed transient ischemic attacks (TIA), stroke, and symptoms of delirium. Among the 35 analyzed patients, only one was diagnosed with symptomatic stroke presenting as paresis with consciousness disorders (confirmed
Tab. II. Analysis of imaging parameters in patients with lesions diagnosed by epicardial ultrasound

\begin{tabular}{lcc} 
Analyzed parameter & $\begin{array}{r}\text { EAS(+) } \\
N=18\end{array}$ & Mean value \\
$\begin{array}{lcc}\text { \% of the diameter affected by the } \\
\text { atherosclerotic lesion }\end{array}$ & $15-40 \%$ & $25.16 \%$ \\
\hline $\begin{array}{l}\text { Number of affected segments in patients } \\
\text { with EAS(+) who also underwent CT }\end{array}$ & $3-6$ & $\begin{array}{c}3.94 \\
\text { (4 segments) }\end{array}$ \\
\hline Atherosclerosis in X-ray & 8 & $44.4 \%$ \\
\hline Calcifications in TTE & 12 & $66.6 \%$ \\
\hline Calcifications in TEE & 7 & $38.8 \%$ \\
\hline
\end{tabular}

EAS - epiaortic ultrasound scanning, CT - computed tomography, TTE - transthoracic echocardiography, TEE - transesophageal echocardiography.

Tab. III. Analysis of clinical parameters, types of procedures, and complications in patients with lesions diagnosed by EAS(+) and in patients without lesions according to the EAS(-) examination

\begin{tabular}{|c|c|c|c|c|c|}
\hline Surgical procedure & $\begin{array}{l}\mathrm{EAS}(+) \\
N=18\end{array}$ & $\begin{array}{l}\text { EAS(-) } \\
N=17\end{array}$ & $\begin{array}{c}\text { EAS(+) } \\
\%\end{array}$ & $\begin{array}{c}\text { EAS(-) } \\
\%\end{array}$ & $P$-value \\
\hline AVR & 6 & 14 & 33.3 & 82.3 & $<0.05$ \\
\hline$A V R+C A B G$ & 5 & 3 & 27.7 & 17.64 & NS \\
\hline$A V R+A A A$ & 4 & 0 & 22.2 & 0 & $<0.05$ \\
\hline CABG/OPCAB & 2 & 0 & 11.1 & 0 & 0.251 \\
\hline Age & 81.2 & 81.5 & - & - & NS \\
\hline Women & 11 & 6 & 61.1 & 35.29 & $<0.05$ \\
\hline Lesions in carotid arteries & 16 & 7 & 83.3 & 41.17 & $<0.05$ \\
\hline Lesions in peripheral arteries & 4 & 3 & 22.22 & 17.64 & NS \\
\hline Diabetes & 6 & 7 & 33.33 & 41.17 & NS \\
\hline Influence of EAS(+) on clamping & 16 & 1 & 83.3 & 5.88 & $<0.001$ \\
\hline Influence of EAS on cannulation & 9 & 0 & 50.0 & 0 & $<0.05$ \\
\hline History of stroke & 2 & 1 & 11.1 & 5.8 & $<0.05$ \\
\hline Perioperative stroke & 0 & 1 & 0 & 11.76 & 0.068 \\
\hline TIA & 1 & 1 & 5.55 & 5.88 & NS \\
\hline Delirium & 2 & 2 & 11.1 & 11.76 & NS \\
\hline
\end{tabular}

EAS - epiaortic ultrasound scanning, AVR - aortic valve replacement, CABG - coronary artery bypass grafting, AAA - abdominal aortic aneurysm, OPCAB - off-pump coronary artery bypass, TIA - transient ischemic attacks.

Tab. IV. Comparison of demographic parameters and the degree of peripheral atherosclerosis in patients with positive and negative epiaortic ultrasound scanning (EAS) results and neurological complications

\begin{tabular}{|c|c|c|c|c|c|c|c|}
\hline Complication & Age & Women & Diabetes & $\begin{array}{l}\text { Lesions } \\
\text { in carotid } \\
\text { arteries }\end{array}$ & $\begin{array}{c}\text { Lesions in } \\
\text { peripheral } \\
\text { arteries }\end{array}$ & $\begin{array}{l}\text { Number of } \\
\text { segments }\end{array}$ & $\begin{array}{c}\% \text { of } \\
\text { diameter } \\
\text { affected }\end{array}$ \\
\hline \multicolumn{8}{|l|}{$\operatorname{EAS}(+), n=18:$} \\
\hline TIA, $n=1(5.55 \%)$ & 81 & 1 & 0 & 1 & 1 & $3-5$ & 30 \\
\hline Delirium, $n=2$ (11.1\%) & 81.2 & 2 & 2 & 1 & 1 & $3-4$ & 23 \\
\hline \multicolumn{8}{|l|}{$\operatorname{EAS}(-), n=17:$} \\
\hline Stroke, $n=1(11.76 \%)$ & 83 & 0 & 0 & 1 & 1 & - & - \\
\hline TIA, $n=1(5.88 \%)$ & 80 & 0 & 0 & 0 & 1 & - & - \\
\hline Delirium, $n=2$ (11.76\%) & 83.5 & 0 & 2 & 1 & 1 & - & - \\
\hline
\end{tabular}

TIA - transient ischemic attacks. 
Tab. V. Predictive parameters which, diagnosed together, demonstrated a significant impact on the confirmation of atherosclerotic changes in epiaortic ultrasound scanning (EAS) and increased the risk of perioperative complications

\section{Clinical/demographic parameter or imaging examination result} in patients with EAS(+)

Female sex

Atherosclerotic changes in carotid vessels

History of stroke

Calcifications observed in transthoracic echocardiography (TTE)

with neurological assessment and head $\mathrm{CT}$ ); 2 patients suffered from TIA, and 3 experienced complications in the form of orientation disorders with delirium described as exogenous syndrome. The TIA was the only complication to occur significantly more often in patients with atherosclerotic changes in the ascending aorta, as confirmed by EAS (Tab. IV).

\section{Impact on the technical aspects of the procedure}

In over $80 \%$ of patients, positive EAS results influenced the selection of the aortic clamp site; in $50 \%$ of cases, such results influenced the selection of the location where the ascending aorta was cannulated so that cardioplegia could be administered to stop the heart.

\section{Conclusions}

In order to sum up the results of the analyzed group of 35 patients, clinical and demographic data were collected and compared with the results of imaging examinations.

Female sex, atherosclerotic lesions in carotid vessels, previous stroke, and calcifications of the ascending aorta visualized by preoperative transthoracic echocardiography proved to be parameters which, when diagnosed together, had a significant influence on confirming atherosclerotic changes with EAS and increased the risk of perioperative complications in patients over 75 years old undergoing AVR (Tab. V).

\section{Discussion}

Perioperative stroke is one of the most common complications in patients undergoing cardiac surgery; its incidence depends on the type of the procedure and the associated risk. The complication is most often encountered during mitral valve repair (8.8\%) and complex procedures such as coronary artery bypass grafting (CABG; $7.4 \%$ ). The rate for non-CABG procedures is $3.8 \%$, for isolated aortic valve surgery $4.8 \%$, and for bypass procedures without extracorporeal circulation or aortic clamping (OPCAB) 1.9\%. Older patients with neurological complications require much longer stays in the intensive care unit, which significantly increases the total cost of hospitalization. In most cases, they are unable to return to their preoperative functional status and require further treatment and rehabilita- tion in the neurological ward or the unit for chronic and terminal patients $[6,7]$.

The main risk factors for neurological complications include elderly age, female sex, previous stroke, cerebrovascular and peripheral artery diseases, atherosclerosis and calcification of the aortic bulb and the ascending aorta, diabetes, arterial hypertension, previous cardiac surgery, urgent procedures with more than 120 min of extracorporeal circulation, and the use of hemofiltration or blood transfusion [8, 9]. Having analyzed 7272 patients undergoing CABG, Kapetanakis et al. demonstrated that minimal manipulation within the aorta resulted in the reduction of perioperative stroke risk by almost $50 \%$, suggesting that unsuccessful outcomes may be caused by embolization with atherosclerotic plaques detached during aortic clamping or cannulation [10]. In the study by Hangler from 2001, changing the treatment strategy based on epiaortic imaging enabled the reduction of stroke incidence to $2.9 \%$ (in comparison to $4.4 \%$ in the control group). A decided majority of elderly surgical patients with intensified generalized atherosclerosis require preoperative aortic evaluation [11]. The use of epicardial ultrasonography and TEE should enable an individualized approach to the condition and the selection of surgical technique, even though most surgeons still prefer to examine patients with palpation. As part of their study, Marshall et al. diagnosed aortic atherosclerosis in over $58 \%$ of elderly patients; the condition was confirmed with palpation in only $24 \%$ of cases [12]. Studies comparing epicardial ultrasonography with pathomorphological assessment of aortic segments and neurological complications confirmed the high sensitivity and efficacy of the epicardial method; however, the studies aiming to assess the influence of ultrasonography on the selection of the method of treatment (and, consequently, prevention of perioperative complications) are limited to relatively small populations $[13,14]$. In one of the latest studies, Bolotin et al. demonstrated the influence of the EAS results on the change of surgical strategy in $28 \%$ out of 105 patients undergoing coronary revascularization (CABG); the modifications pertained to the sites of aortic clamping and cannulation, locations where the proximal bypass segments were sutured in, and, in individual cases, resection of the changed aortic segment [15]. Zingone from a center in Triest, on the basis of EAS performed in 690 consecutive patients, detected from 1 to 12 significantly atherosclerosed aortic segments in $21.4 \%$ of patients (in the subgroup of patients with concomitant aortic valve disease and advanced coronary artery disease, the percentage was as high as 54.1\%), which often forced the surgeon to replace the significantly changed segments [16]. The remaining studies confirm the association between atherosclerotic changes in this patient group and the risk of cerebral embolism and ischemic stroke (7.4-8.4\%). Only a few studies have demonstrated significantly greater accuracy of EAS over palpation and over TEE, which does not visualize the marginal segment of the ascending aorta or the aortic arch. Although complications after epicardial ultrasonography are very rare, the 
method is associated with some limitations, such as the longer time between the opening of the chest and the start of extracorporeal circulation (especially if older equipment is used or the surgeon's experience is not extensive) or, to a certain degree, the risk of operative field contamination. Only some authors believe that EAS should be performed solely to confirm and better distinguish changes suspected after TEE or in cases with contraindications for transesophageal examination [17].

\section{Acknowledgments}

The study was supported by a research grant from the Medical University of Silesia (no. KNW-1-160/N/3/0 and KNW-1-162/N/4/0).

\section{Disclosure}

The authors report no conflict of interest.

\section{References}

1. Hogue CW Jr, Barzilai B, Pieper KS, Coombs LP, DeLong ER, Kouchoukos NT, Dávila-Román VG. Sex differences in neurological outcomes and mortality after cardiac surgery: a Society of Thoracic Surgery National Database Report. Circulation 2001; 103: 2133-2137.

2. Mishra M, Khurana P, Meharwal ZS, Trehan N. A comparative study of imaging techniques in aortic dissection, DeBakey type I: intraoperative live three-dimensional epicardial echocardiography, multiplane transesophageal echocardiography, and multislice computed tomography. Innovations (Phila) 2005; 1: 40-47.

3. Nemes A, Forster T, Gruber N, Csanády M. [Aortic distensibility indices evaluated by transoesophageal echocardiography in patients with coronary artery disease or aortic valve stenosis]. Orv Hetil 2004 145: 1931-1935.

4. Iglesias I, Bainbridge D, Murkin J. Intraoperative echocardiography: support for decision making in cardiac surgery. Semin Cardiothorac Vasc Anesth 2004; 8: 25-35.
5. Sangalli F, Formica F, Manetti B, Trabucchi M, Avalli L, Paolini G, Pesenti A A systematic approach to substernal epicardial echocardiographic examination. J Cardiothorac Vasc Anesth 2007; 21: 237-242.

6. Puskas JD, Winston AD, Wright CE, Gott JP, Brown WM III, Craver JM, Jones EL, Guyton RA, Weintraub WS. Stroke after coronary artery operation: incidence, correlates, outcome, and cost. Ann Thorac Surg 2000; 69: 1053-1056.

7. John R, Choudhri AF, Weinberg AD, Ting W, Rose EA, Smith CR, Oz MC. Multicenter review of preoperative risk factors for stroke after coronary artery bypass grafting. Ann Thorac Surg 2000; 69: 30-36.

8. Cleveland JC Jr, Shroyer AL, Chen AY, Peterson E, Grover FL. Off-pump coronary artery bypass grafting decreases risk-adjusted mortality and morbidity. Ann Thorac Surg 2001; 72: 1282-1289.

9. Bucerius J, Gummert JF, Borger MA, Walther T, Doll N, Onnasch JF, Metz S, Falk V, Mohr FW. Stroke after cardiac surgery: a risk factor analysis of 16,184 consecutive adult patients. Ann Thorac Surg 2003; 75: 472-478.

10. Kapetanakis El, Stamou SC, Dullum MK, Hill PC, Haile E, Boyce SW, Bafi AS, Petro KR, Corso PJ. The impact of aortic manipulation on neurologic outcomes after coronary artery bypass surgery: a risk-adjusted study. Ann Thorac Surg 2004; 78: 1564-1571.

11. Hangler HB, Nagele G, Danzmayr M, Mueller L, Ruttmann E, Laufer G, Bonatti J. Modification of surgical technique for ascending aortic atherosclerosis: impact on stroke reduction in coronary artery bypass grafting. J Thorac Cardiovasc Surg 2003; 126: 391-400

12. Marshall WG Jr, Barzilai B, Kouchoukos NT, Saffitz J. Intraoperative ultrasonic imaging of the ascending aorta. Ann Thorac Surg 1989; 48: 339-344.

13. Eltzschig HK, Kallmeyer IJ, Mihaljevic T, Alapati S, Shernan SK. A practical approach to a comprehensive epicardial and epiaortic echocardiographic examination. J Cardiothorac Vasc Anesth 2003; 17: 422-429.

14. Frenk VE, Shernan SK, Eltzschig HK. Epicardial echocardiography: diagnostics utility for evaluating aortic valve disease during coronary surgery. J Clin Anesth 2003; 15: 271-274.

15. Bolotin G, Domany Y, de Perini L, Frolkis I, Lev-Ran O, Nesher N, Uretzky G. Use of intraoperative epiaortic ultrasonography to delineate aortic atheroma. Chest 2005; 127: 60-65.

16. Zingone B, Rauber E, Gatti G, Pappalardo A, Benussi B, Dreas L, Lattuada L The impact of epiaortic ultrasonographic scanning on the risk of perioperative stroke. Eur J Cardiothorac Surg 2006; 29: 720-728.

17. Djaiani G, Ali M, Borger MA, Woo A, Carroll J, Feindel C, Fedorko L, Karski J, Rakowski H. Epiaortic scanning modifies planned intraoperative surgical management but not cerebral embolic load during coronary artery bypass surgery. Anesth Analg 2008; 106: 1611-1618. 